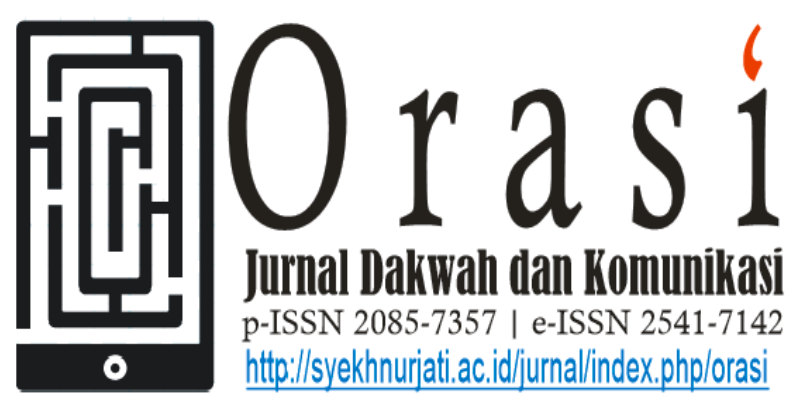

Volume 10 No. 2 Desember 2019

\title{
PESAN DAKWAH TENTANG $K$-WAVERS HIJRAH DI MEDIA SOSIAL INSTAGRAM
}

\section{DA'WAH MESSAGE ABOUT K-WAVERS HIJRAH IN INSTAGRAM SOCIAL MEDIA}

\author{
Asriyanti Rosmalina ${ }^{1}$, dan Fawaz Altop Zulfikar ${ }^{2}$ \\ ${ }^{1}$ Program Studi Komunikasi dan Penyiaran Islam, IAIN Syekh Nurjati Cirebon \\ ${ }^{2}$ Department of Biology, Faculty of Science and Technology, UIN Sunan Gunung Djati Bandung, \\ le-mail:rossmalina@yahoo.com \\ 2e-mail: altoffawaz@gmail.com
}

\begin{abstract}
ABSTRAK
Dakwah adalah suatu agenda harian yang sudah tentu menjadi kewajiban oleh seluruh umat muslim. Pesan dakwah adalah segala sesuatu yang disampaikan oleh $d a^{\prime} i$ kepada mad'u. Internet sebagai jaringan komunikasi yang bisa menghubungkan seluruh orang didunia termasuk memudahkan para da'i untuk menyampaikan pesan dakwah seperti di media sosial sehingga semua masyarakat dapat mengetahui perkembangan Islam secara beragam dan menyeluruh. Instagram adalah salah satu media sosial yang sering digunakan dan memiliki beragam fitur yang menarik. Salah satu akun instagram yang fokus mengunggah motivasi untuk kalangan penggemar hiburan yang berasal dari Korea (gelombang korea) yang berniat hijrah, yaitu akun X Korean Wavers (@xkwavers). Makna pesan dakwah pada tiga postingan pertama akun instagram @xkwaves, yaitu sebagai berikut, cinta yang berlebihan kepada makhluk tidak akan pernah baik hasilnya. Dalam konteks ini cinta kepada budaya asing (baca: Korea), yang pada akhirnya hanya akan menenggelamkan yang mencintai pada hal-hal yang negatif. Sebagaimana diketahui bahwa cinta pada dasarnya adalah fitrah setiap manusia yang dianugerahkan oleh Allah Swt. Segala sesuatu tergantung pada niatnya. Hidayah itu dicari, bukan dinanti. Allah Swt tidak akan serta merta mengubah nasib seseorang hingga orang itu berusaha untuk merubah nasibnya sendiri. Saling mencintai di antara sesama Muslim, dalam bingkai Ukhuwah Islamiyyah. Pentingnya menjaga hati. "Ketahuilah, di dalam tubuh terdapat segumpal darah, jika ia baik maka akan baiklah seluruh tubuh. Namun jika ia rusak maka akan rusak pulalah seluruh tubuh, ketahuilah bahwa segumpal darah tersebut adalah hati."
\end{abstract}

Orasi: Jurnal Dakwah dan Komunikasi | Volume 10, No. 2, Desember 2019 
Kata Kunci: Dakwah, Gelombang Korea, Instagram, Pesan Dakwah

\begin{abstract}
Da'wah is a daily agenda which is certainly an obligation of all Muslims. The message of da'wah is everything that the preacher conveys to you. The internet as a communication network that can connect all people in the world including making it easier for preachers to deliver da'wah messages such as on social media so that all people can know the development of Islam in a diverse and comprehensive manner. Instagram is a social media that is often used and has a variety of interesting features. One Instagram account that focuses on uploading motivation for entertainment fans from Korea (the Korean wave) who intends to move, is the X Korean Wavers account (@xkwavers). The meaning of da'wah messages on the first three posts on the @xkwaves Instagram account, which is as follows, excessive love for beings will never be good. In this context love for foreign cultures (read: Korea), which in the end will only drown those who love negative things. As is known that love is basically the nature of every human being bestowed by Allah. Everything depends on his intention. Hidayah is sought, not anticipated. Allah (swt) will not necessarily change a person's destiny until that person tries to change his own destiny. Love each other among Muslims, in the frame of Ukhuwah Islamiyyah. The importance of guarding the heart. "Know! In the body there is a clot of blood, if it is good then the whole body will be fine. But if it is damaged, it will also damage the whole body, know that the blood clot is the heart."
\end{abstract}

Keywords: Da'wah, Instagram, Korean Wave, Da'wah Messages

\section{Pendahuluan}

Dakwah adalah suatu agenda harian yang sudah tentu menjadi kewajiban oleh seluruh umat muslim. Dakwah dapat juga dikatakan sebagai suatu bentuk gejala sosial dalam diri seseorang atau pada masyarakat yang berkaitan dengan perilaku menyimpang dari ajaran Allah Swt. Dakwah dapat dikatakan sebagai suatu proses penyampaian pesan dari da'i (orang yang berdakwah) kepada mad'u (orang yang didakwahkan) untuk senantiasa berada di jalan Allah dengan cara menjauhi segala jenis larangan-Nya dan menjalankan seluruh perintah-Nya. Pada pelaksanaannya, dakwah tidak dibatasi oleh ruang dan waktu. Dalam proses penyampaiannya, setiap orang mempunyai kemampuan masing-masing ketika berdakwah yang tidak selalu bisa berdiri di depan mimbar. Menurut Ismail, dkk (2018), proses dakwah dapat dilaksanakan melalui beberapa kegiatan dalam bentuk lisan atau tulisan (dakwah bi al-lisan wa bi al-qalam) dan juga bisa bisa dengan perilaku atau perbuatan (dakwah bil-hal).

Perkembangan teknologi yang begitu pesat yang terwujud pada televisi, radio, maupun media sosial dapat dijadikan sebagai suatu media untuk berdakwah. Pada media televisi, yang dimanfaatkan untuk berdakwah salah satu contohnya adalah Ustadzah Mamah Dedeh dalam program acara "Rumah Mamah 
Dedeh" yang tayang di channel TvOne. Pada media radio, yang dimanfaatkan untuk berdakwah salah satu contohnya adalah stasiun radio MQFM Bandung dan Yogyakarta, yang bahkan secara menyeluruh dimanfaatkan untuk berdakwah dan dapat diakses secara luas melalalui sistem dalam jaringan (daring atau online). Sementara pada media sosial, sebagai contoh pada instagram, terdapat banyak akun para da'i dan da'iah, seperti akun Ustadz Abdul Somad, Lc.,M.A (@ustadzabdulsomad_official),

UstadzAdiHidayat,lc.,M.A(@adihidayatofficia 1, Ustadz Hanan Attaki, Lc.,M.A (@hanan_attaki), Ustadzah Haneen Akira (@haneenakira), Ustadzah Halimah Al-Aydrus (@halimahalaydrus), dan masih banyak akun pendakwah yang lainnya.

Kehadiran berbagai media tersebut dapat dimanfaatkan di tengah masyarakat untuk menyampaikan pesan dakwah, khususnya melalui internet. Perkembangan internet berdampak terhadap kegiatan yang pada awalnya terasa sulit menjadi mudah. Internet sebagai jaringan komunikasi yang bisa menghubungkan seluruh orang didunia termasuk memudahkan para da'i untuk menyampaikan pesan dakwah seperti di media sosial sehingga semua masyarakat dapat mengetahui perkembangan Islam secara beragam dan menyeluruh. Media sosial ini banyak digunakan oleh generasi milenial, maka dengan berdakwah di media, khususnya media sosial menarik untuk para remaja. Media sosial tidak terlepas dari sisi negatif, banyak kejahatan yang dilakukan akibat penyalahgunaan media sosial, seperti penipuan, penculikan bahkan pembunuhan dan yang marak pobia, akan tetapi media sosial juga memiliki banyak sisi pesan positif jika diarahkan pada pesan pesan dakwah, terutama pesan pesan yang berkaitan dengan remaja yaitu tentang hijrah dari dunia hiburan Korea.

Instagram adalah salah satu media sosial yang sering digunakan dan memiliki beragam fitur yang menarik. Instagram, seperti yang telah diutarakan sebelumnya, dapat berperan dalam mensyiarkan ajaran Islam dengan cara menggunggah foto maupun video yang disertakan deskripsi (caption) pesan-pesan oleh sang pemilik akun. Salah satu akun instagram yang fokus mengunggah motivasi untuk kalangan penggemar hiburan yang berasal dari Negeri Gingseng, Korea, yaitu akunX Korean Wavers (@xkwavers), akun ini dibuat untuk merangkul tanpa memukul, memberi solusi tanpa membenci, dan mengatasi "Halu" (halusinasi) kepada "Hallyu" (demam Korea), sekaligus menjembatani para penikmat dunia hiburan Korea yang ingin berhijrah untuk menghilangkan rasa fanatisme yang berlebihan.

Akun@xkwavers ini mempunyai 43.800 pengikut dan 99 unggahan. Akun ini pertama kali mengunggah pada tanggal 31 Agustus 2018. Unggahan akun@xkwavers banyak mengandung pesan dakwah yang memotivasi tentang hijrah dari fanaisme dunia hiburan Korea, dengan menggunakan bahasa yang mudah dipahami oleh kalangan remaja.

Pesan yang akan diteliti dalam 
instagram ini adalah pesan-pesan tentang hijrah dari fanatisme dunia hiburan Korea. Dalam konteks ini, maka dilihat dari unggahan pada akun@xkwavers. Peneliti menganggap masalah ini menarik untuk diteliti dan dibahas dengan judul Pesan Dakwah Tentang $K$-Wavers Hijrah Di Media Sosial Instagram. Peneliti merumuskan di dalam pertanyaan, bagaimana makna pesan dakwah tentang k-wavers hijrah dalam tiga unggahan pertama akun instagram@xkwavers?

\section{Landasan Teoritis}

Dakwah secara etimologis (lughatan) berasal dari kata $d a^{\prime} a$, yad'u, da'watan. Kata $d a ' a$ mengandung arti, menyeru, memanggil, dan mengajak. Dakwah artinya seruan, panggilan, dan ajakan. Dakwah Islam dapat dipahami sebagai seruan, panggilan, dan ajakan kepada Islam. Dakwah juga dapat didefinisikan sebagai suatu kegiatan mengajak, mendorong, dan memotivasi orang lain berdasarkan bashirah untuk meniti jalan Allah dan istiqomah di jalan-Nya, serta berjuang bersama untuk meninggikan agama Allah (Illaihi, dan Harjani, 2018).

Menurut Aziz (2017), ditinjau dari segi bahasa, dakwah berasal dari bahasa Arab “da'wah". Da'wah mempunyai tiga huruf asal, yaitu dal, 'ain, dan wawu. Dari ketiga huruf asal ini, terbentuk beberapa kata dan ragam makna. Makna tersebut adalah memanggil, mengundang, meminta tolong, meminta, memohon, menamakan, menyuruh datang, mendorong, menyebabkan, mendatangkan, mendo'akan, menangisi, dan meratapi. Di dalam Al-Qur'an, kata da'wah dan berbagai bentuk katanya ditemyukan sebanyak 198 kali menurut hitungan Muhammad Sulthon, 299 kali menurut hitungan Muhammad Fu'ad 'Abd al-Baqi', atau 212 kali menurut Asep Muhidin. Hal tersebut menandakan bahwa Al-Qur'an mengembangkan makna dari kata da'wah untuk berbagai penggunaan.

Al-Qur'an sebagai kitab suci umat Islam tentu telah memberikan makna tersendiri tentang dakwah. Di dalam Al-Qur'an, identifikasi mengenai dakwah terbagi menjadi tiga jenis, yaitu pertama sebagai panggilan (aktualisasi) iman (termuat di dalam QS. Al-Anfaâl [8] ayat 24:

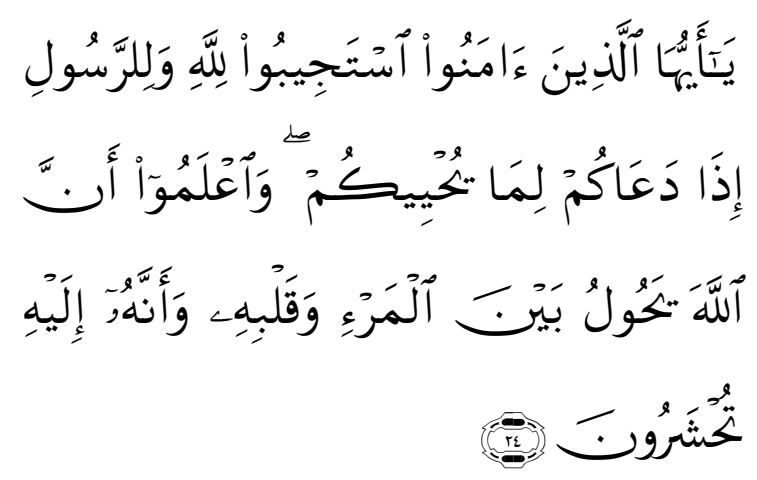

"Hai orang-orang yang beriman, penuhilah seruan Allah dan seruan Rasul apabila Rasul menyeru kamu kepada suatu yang memberi kehidupan kepada kamu, ketahuilah bahwa sesungguhnya Allah membatasi antara manusia dan hatinya dan sesungguhnya kepada-Nya-lah kamu akan dikumpulkan."

Kedua, dakwah juga dapat diidentifikasi sebagai pencerahan agama, yang terdapat di dalam QS. Ibrahim [14] ayat 5:

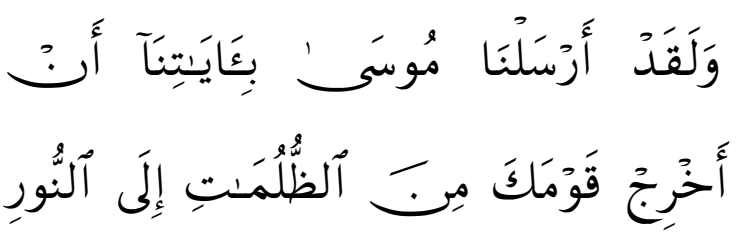




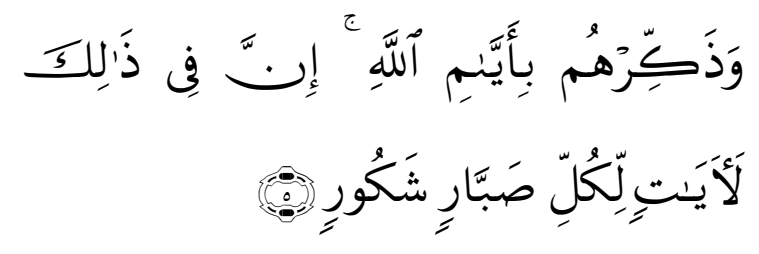

"Dan sesungguhnya Kami telah mengutus Musa dengan membawa ayat-ayat Kami, (dan Kami perintahkan kepadanya): "Keluarkanlah kaummu dari gelap gulita kepada cahaya terang benderang dan ingatkanlah mereka kepada hari-hari Allah". Sesunguhnya pada yang demikian itu terdapat tanda-tanda (kekuasaan Allah) bagi setiap orang penyabar dan banyak bersyukur."

Ketiga, dakwah juga dapat diidentifikasi sebagai suatu proses pemberdayaan masyarakat menuju kualitas terbaik (khair-a ummah), yang terdapat di dalam QS. Ali Imran [3] ayat 110:

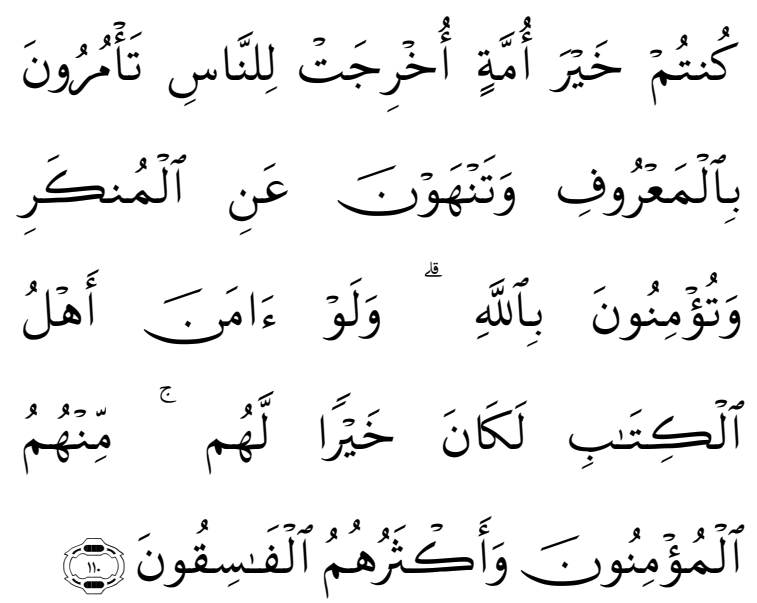

"Kamu adalah umat yang terbaik yang dilahirkan untuk manusia, menyuruh kepada yang ma'ruf, dan mencegah dari yang munkar, dan beriman kepada Allah. Sekiranya Ahli Kitab beriman, tentulah itu lebih baik bagi mereka, di antara mereka ada yang beriman, dan kebanyakan mereka adalah orang-orang yang fasik."

Merujuk kepada tiga ayat di atas, Syekh Ali Mahfuzh memahami dakwah sebagai suatu kegiatan menyeru dan mengajak manusia kepada petunjuk Tuhan, serta melakukan amar makruf dan nahi munkar demi mencapai kebaikan dunia dan akhirat. Lebih luas dari pendapat Ali Mahfuzh, Sanusi memahami dakwah sebagai proses Islamisasi total dan menyeluruh terhadap semua segi kehidupan masyarakat. Pandangan serupa juga dikemukakan oleh Adnan Khalil Pasha yang memandang dakwah sebagai suatu usaha dan respons kaum beriman dalam menjawab berbagai jenis persoalan dan permasalahan yang terjadi di tengah-tengah masyarakat (Ismail, 2018).

Selain tiga ayat di atas, menurut Aziz (2017), setidaknya terdapat sepuluh macam makna dakwah di dalam Al-Qur'an.

Mengajak dan menyeru, baik kepada kebaikan maupun kemusyrikan; kepada jalan ke surga atau ke neraka. Makna ini paling banyak menghiasi ayat-ayat Al-Qur'an, yaitu sebnayak 46 kali. Kebanyakan drai makna ini mengarah kepada jalan keimanan, yaitu sebanyak 39 kali. Di antara dua jalan berlawanan yang menggunakan kata dakwah adalah QS. Al-Baqarah [2] ayat 221:
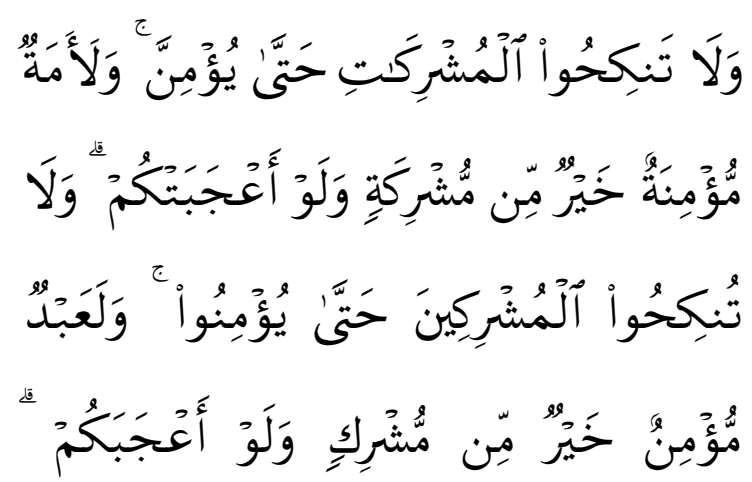

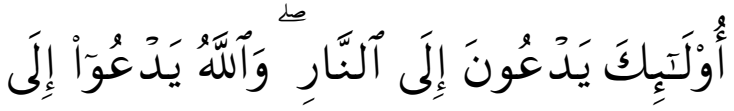




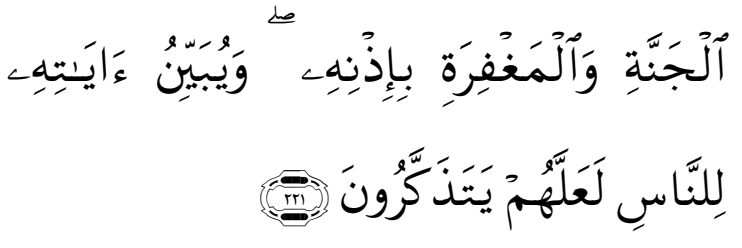

"Dan janganlah kamu menikahi wanita-wanita musyrik, sebelum mereka beriman. Sesungguhnya wanita budak yang mukmin lebih baik dari wanita musyrik, walaupun dia menarik hatimu. Dan janganlah kamu menikahkan orang-orang musyrik (dengan wanita-wanita mukmin) sebelum mereka beriman. Sesungguhnya budak yang mukmin lebih baik dari orang musyrik, walaupun dia menarik hatimu. Mereka mengajak ke neraka, sedang Allah mengajak ke surga dan ampunan dengan izin-Nya. Dan Allah menerangkan ayat-ayat-Nya (perintah-perintah-Nya) kepada manusia supaya mereka mengambil pelajaran."

Do'a, seperti di dalam QS. Ali Imran

[3] ayat 38:

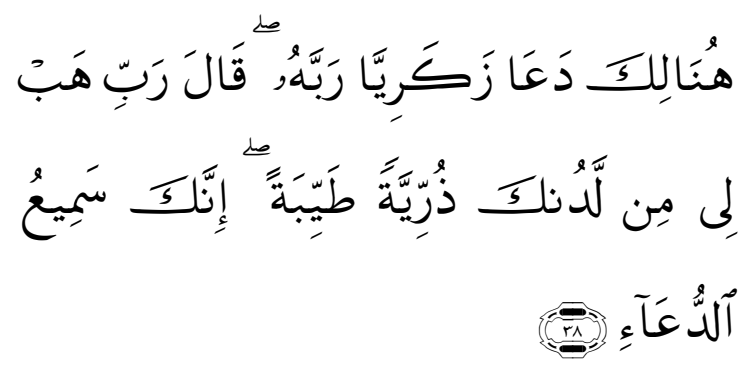

"Di sanalah Zakariya mendoa kepada Tuhannya seraya berkata: "Ya Tuhanku, berilah aku dari sisi Engkau seorang anak yang baik. Sesungguhnya Engkau Maha Pendengar doa."

Mendakwa atau menganggap tidak baik, seperti yang terdapat di dalam QS. Maryam [19] ayat 91:

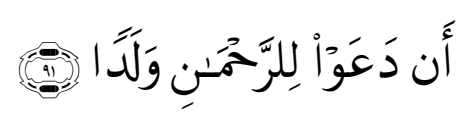

"karena mereka mendakwakan Allah Yang Maha Pemurah mempunyai anak."

Mengadu, seperti yang terdapat di dalam QS. Al-Qamar [54] ayat 10:

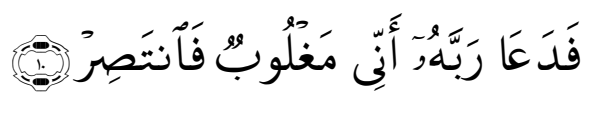

"Maka dia mengadu kepada Tuhannya: "bahwasanya aku ini adalah orang yang dikalahkan, oleh sebab itu menangkanlah (aku)."

Memanggil atau panggilan, sebagaimana yang terdapat di dalam QS. Ar-Rum [30] ayat 25:

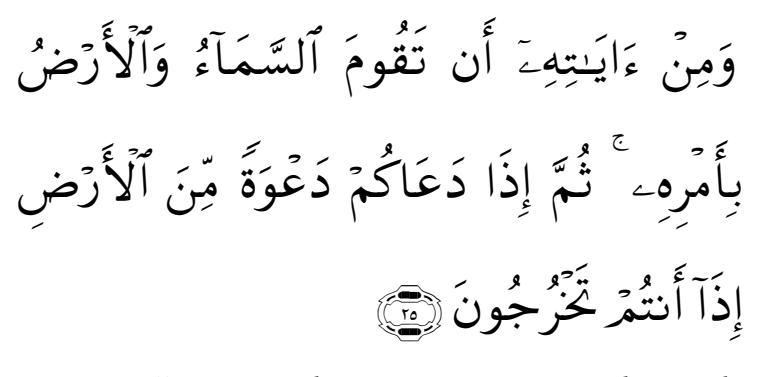

"Dan di antara tanda-tanda kekuasaan-Nya ialah berdirinya langit dan bumi dengan iradat-Nya. Kemudian apabila Dia memanggil kamu sekali panggil dari bumi, seketika itu (juga) kamu keluar (dari kubur)."

Meminta, seperti yang terdapat di dalam QS. Shad [38] ayat 51:

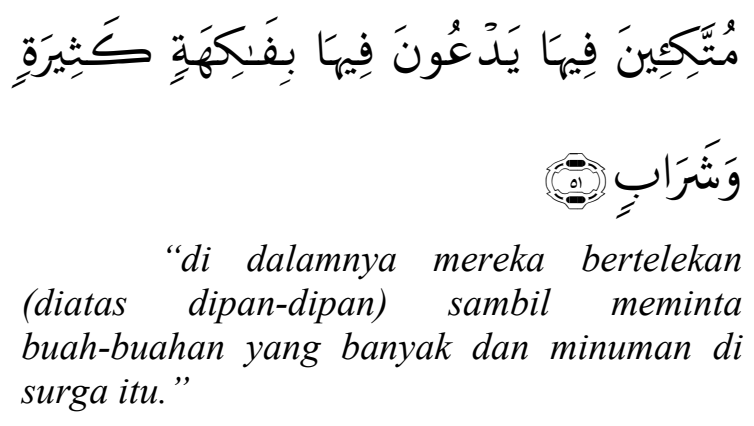

Mengundang, sebagaimana yang terdapat di dalam QS. Al-Qashash [28] ayat 25:

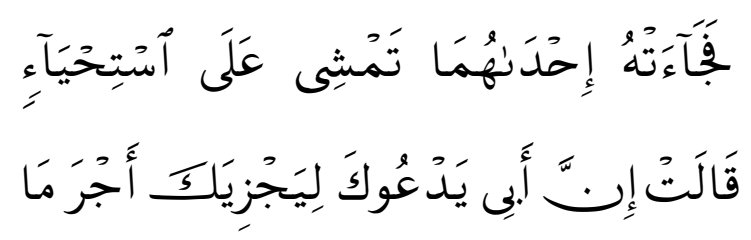




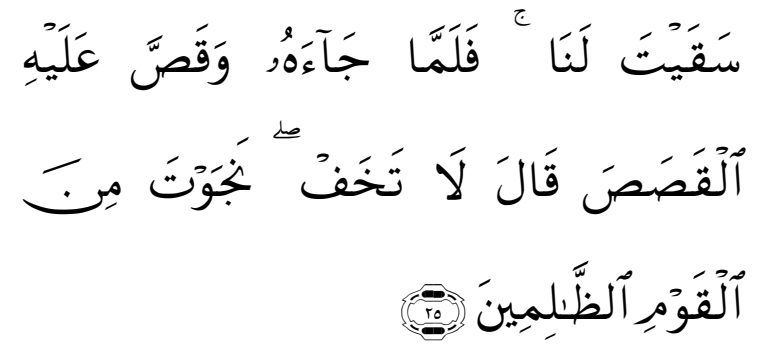

"Kemudian datanglah kepada Musa salah seorang dari kedua wanita itu berjalan kemalu-maluan, ia berkata: "Sesungguhnya bapakku memanggil kamu agar ia memberikan balasan terhadap (kebaikan)mu memberi minum (ternak) kami". Maka tatkala Musa mendatangi bapaknya (Syu'aib) dan menceritakan kepadanya cerita (mengenai dirinya), Syu'aib berkata: "Janganlah kamu takut. Kamu telah selamat dari orang-orang yang zalim itu."

Malaikat Israfil sebagai penyeru, yaitu terdapat di dalam QS. Thaha [20] ayat 108:

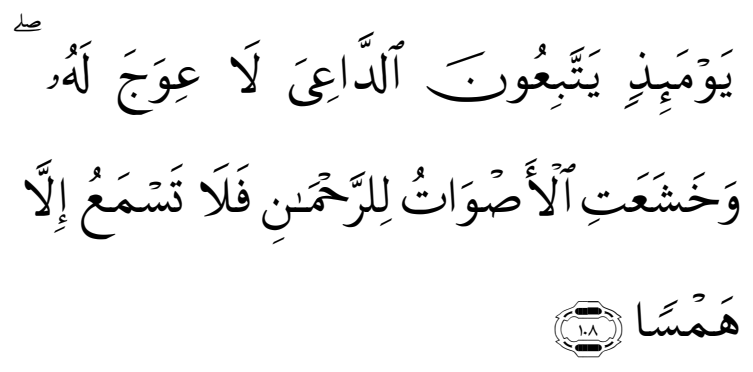

"Pada hari itu manusia mengikuti (menuju kepada suara) penyeru dengan tidak berbelok-belok; dan merendahlah semua suara kepada Tuhan Yang Maha Pemurah, maka kamu tidak mendengar kecuali bisikan saja."

$$
\text { Panggilan nama atau gelar, }
$$
sebagaimana yang terdapat di dalam QS. An-Nur [24] ayat 63:

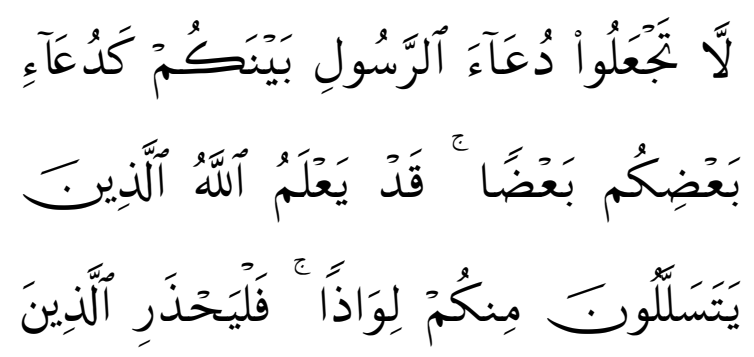

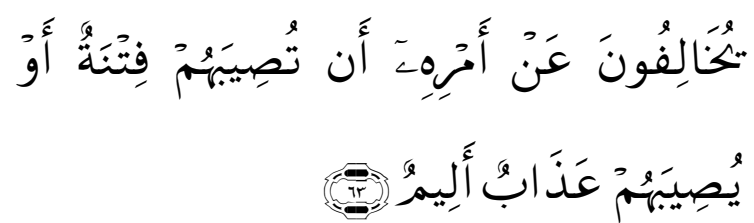

"Janganlah kamu jadikan panggilan Rasul diantara kamu seperti panggilan sebahagian kamu kepada sebahagian (yang lain). Sesungguhnya Allah telah mengetahui orang-orang yang berangsur-angsur pergi di antara kamu dengan berlindung (kepada kawannya), maka hendaklah orang-orang yang menyalahi perintah Rasul takut akan ditimpa cobaan atau ditimpa azab yang pedih."

Anak angkat, yaitu terdapat di dalam QS. Al-Ahzab [33] ayat 4:
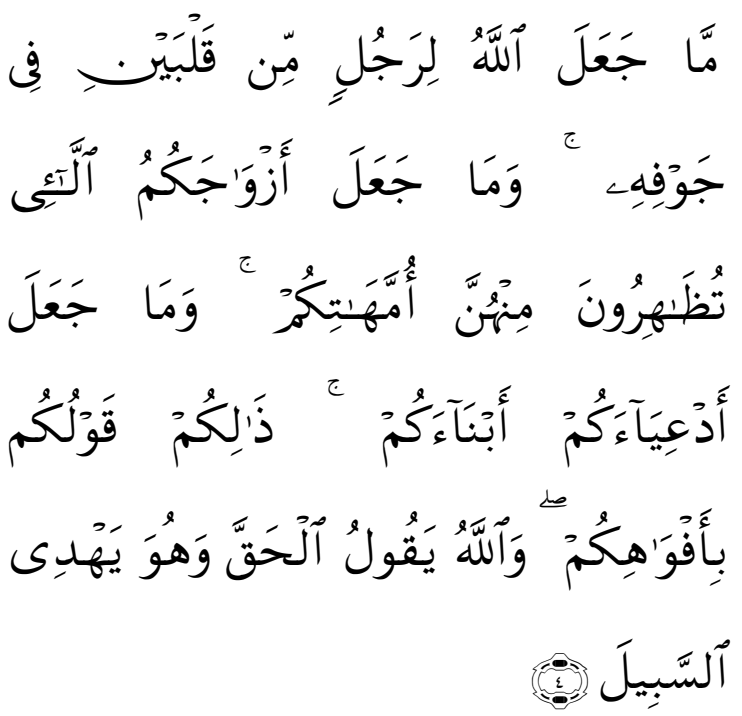

"Allah sekali-kali tidak menjadikan bagi seseorang dua buah hati dalam rongganya; dan Dia tidak menjadikan istri-istrimu yang kamu zhihar itu sebagai ibumu, dan Dia tidak menjadikan anak-anak angkatmu sebagai anak kandungmu (sendiri). Yang demikian itu hanyalah perkataanmu di mulutmu saja. Dan Allah mengatakan yang sebenarnya dan Dia menunjukkan jalan (yang benar)."

Konsep dakwah lainnya disampaikan oleh Prof. Muhammad Jamil, yang sungguh komprehensif, sebagai suatu transformasi sosial dan kultural menuju kemajuan Islam. Prof. Muhammad Jamil berpendapat bahwa, 
pengertian yang umum mengenai dakwah ialah bahwa dakwah dipahami sebagai nasihat, ceramah, dan menyampaikan pidato di masjid-masjid. Padahal hakikat dakwah yang sebenarnya jauh lebih luas daripada itu. Dakwah pada dasarnya adalah kata-kata, perbuatan, dan sekaligus perilaku. Medan dakwah sangat beragam, dapat dilakukan di madrasah, perguruan tinggi, institusi-institusi pendidikan, mal, dan perusahaan, dapat juga dilakukan di samping masjid, perkumpulan, dan organisasi-organisasi lain yang beraneka ragam bentuk dan jenisnya. Tujuannya secara singkat dapat dikemukakaan iala untuk mewujudkan agama Islam dalam semua segi kehidupan masyarakat Islam, baik akidah, syariah maupun akhlak (Jamil, 1980; dalam Ismail, 2018).

Dalam pengertiannya yang lebih luas, dakwah sebagaimana pemahaman Sayyid Quthub adalah sebagai suatu usaha untuk menegakkan sistem Islam (iqamat al-manhaj al-Islamiy) dan juga sebagai suatu perjuangan membangun komunitas dan masyarakat Islam (iqamat al-mujtama' al-Islamiy) di dalam realitas kehidupan, baik pada tataran individu (fardiyyah), keluarga (al-usrah), masyarakat (al-mujtam), dan juga negara (al-daulah) (Quthub, 1982; dalam Ismail, 2018).

Berbagai pendapat dan pandangan yang luas tentang definisi dakwah di atas bertujuan untuk menolak suatu kesalahpahaman (missunderstanding) mengenai dakwah yang terjadi selama ini. Dakwah tidak terbatas pada suatu pemahaman yang merujuk sebagai ceramah atau pidato (tabligh) semata. Dakwah pada hakikatnya mengandung makna transformasi dan pemberdayaan masyarakat (ishlah al-mujtama') melalui perbaikan total terhadap semua aspek kehidupan manusia, yang meliputi aspek agama, ekonomi, pendidikan, politik, dan sosial budaya. Semuanya bertujuan untuk membawa masyarakat dan umat Islam menuju kualitas "khaira ummah" seperti yang dicita-citakan dan terdapat dalam QS. Ali Imran [3]: ayat 110.

Pesan dakwah adalah segala sesuatu yang disampaikan oleh da'i kepada mad'u. Menurut Aziz (2017), di dalam ilmu komunikasi, diketahui bahwa pesan dakwah adalah message, yaitu simbol-simbol. Dalam literatur berbahasa Arab, pesan dakwah disebut maudhu' al-da'wah. Istilah ini lebih tepat dibandingkan dengan istilah "materi dakwah" yang diterjemahkan dalam bahasa Arab menjadi maaddah al-da'wah. Sebutan yang terakhir ini dapat menimbulkan kesalahpahaman sebagai logistik dakwah. Istilah pesan dakwah dianggap lebih tepat untuk menjelaskan "isi dakwah yang dapat berupa kata, gambar, lukisan, dan sebagainya, yang juga diharapkan dapat memberikan pemahaman bahkan perubahan sikap dan perilaku dari mitra dakwah". Jika dakwah melalui tulisan umpamanya, maka yang ditulis itulah yang merupakan pesan dakwah. Jika melalui lisan, maka yang diucapkan pembicara itulah yang disebut sebagai pesan dakwah. Jika melalui tindakan, maka perbuatan baik yang dilakukan tersebutlah yang dinamakan sebagai pesan dakwah. 
Menurut Islami, dkk (2018), pesan dakwah menurut istilah ialah segala jenis bahan ataupun sumber yang dipergunakan atau yang akan disampaikan oleh da'i kepada mad'u dalam kegiatan dakwah, dengan tujuan tercapainya kegiatan dakwah tersebut. Sedangkan menurut Tasmara (1997), pesan dakwah bersumber dari Al-Qur'an dan Sunnah, yang diyakini sebagai pedoman bagi setiap tindak kehidupan dan pola tingkah orang Muslim.

Pada prinsipnya, pesan apapun dapat dijadikan sebagai pesan dakwah selama tidak bertentangan dengan sumber utamanya, yaitu Al-Qur'an dan Hadist (As-Sunnah). Dengan dmeikian, semua pesan yang bertentangan terhadap Al-Qur'an dan Hadits tidak dapat disebut sebagai pesan dakwah. Semua orang dapat berbicara tentang moral, bahkan dengan mengutip ayat Al-Qur'an sekalipun. Akan tetapi, jika hal tersebut dimaksudkan untuk pembenaran atau dasar bagi kepentingan nafsunya semata, maka yang demikian tersebut bukan termasuk ke dalam pesan dakwah. Pesan dakwah pada garis besarnya terbagi menjadi dua, yaitu pesan utama (Al-Qur'an dan Hadits) dan pesan tambahan atu penunjang (selain Al-Qur'an dan Haidts) (Aziz, 2017). Dari berbagai pendapat di atas maka pesan dakwah adalah pesan yang dimaksudkan agar manusia mau dan dapat menerima serta memahami dan sekaligus mengikuti ajaran Islam sehingga benar-benar diketahui, dipahami, dihayati, dan selanjutkan dapat diamalkan sebagai pedoman kehidupan.

Menurut Ismail, dkk (2018), sumber pesan dakwah yaitu dari Al-Qu'an, As-Sunnah dan riwayat hidup Rasulullah. Pada dasarnya, Al-Qur'an merupakan dakwah yang paling kuat untuk pengemban Islam. Di dalam Al-Qur'an mencakup semua cerita orang-orang yang terdahulu beserta hukum-hukumnya. Sejarah hidup Rasulullah juga merupakan bagian yang terpenting bagi kaum Muslim untuk berdakwah. Adapun di dalamnya terdapat beberapa klasifikasi ayat tentang kehidupan, yang dapat dikategorikan untuk penyampaian pesan dakwah.

Menurut Muhiddin (2002; dalam Aziz, 2017), terdapat setidaknya sepuluh rumusan pesan dakwah, yaitu:

- Menjelaskan hakikat tiga rukun di dalam agama Islam, yaitu rukun iman, Islam, dan ihsan yang didakwahkan oleh para Nabi dan Rasul.

- Menjelaskan segala sesuatu yang belum diketahui oleh manusia tentang hakikat kenabian, risalah, dan juga tugas para Rasul Allah Swt.

- Menyempurnakan aspek psikologis manusia secara individu, kelompok, dan masyarakat.

- Mereformasi kehidupan sosial kemasyarakatan dan sosial politik di atas dasar kesatuan nilai kedamaian dan keselamatan dalam agama.

- Mengukuhkan keistimewaan universalitas ajaran Islam dalam pembentukan kepribadian melalui kewajiban dan larangan.

- Menjelaskan hukum Islam tentang kehidupan politik negara. 
- Mmebimbing penggunaan urusan harta.

- Mereformasi sistem peperangan untuk mewujudkan kebaikan dan kemashlahatan umat manusia dan mencegah terjadinya suatu dehumanisasi.

- Menjamin dan memberikan kedudukan yang layak bagi hak-hak kemanusiaan wanita di dalam beragama dan berbudaya.

- Membebaskan perbudakan.

Sepuluh klasifikasi tersebut bermuara pada tiga hubungan interaksi, yaitu Allah Swt (sebagai Pencipta Alam), manusia (sebagai Khalifah), dan alam semesta (sebagai mitra manusia). Ketiga interaksi ini mengembangkan pesan-pesan dakwah. Karena pesan dakwah hanya ditujukan kepada manusia, maka pesan dakwah memiliki karakter yang dimiliki oleh manusia. Dengan kata lain, pesan dakwah disesuaikan dengan karakter dan kedudukan manusia. Menurut Aziz (2017), terdapat tujuh karakteristik pesan dakwah, yaitu orisinal dari Allah Swt, mudah, lengkap, seimbang, universal, masuk akal, dan membawa kebaikan.

Istilah yang kini merujuk pada popularitas hiburan dan budaya Korea di Asia dan daerah lain di dunia, Hallyu atau "Gelombang Korea" (Korean Wave atau K-Wave) muncul pada pertengahan tahun 1990an setelah Korea mengadakan hubungan diplomatik dengan Tiongkok pada tahun 1992, kemudian Drama TV Korea serta musik popnya yang mendapatkan popularitas di antara komunitas berbahasa Cina. Salah satu drama TV Korea yang sukses adalah What Is Love? yang ditayangkan oleh CCTV tahun
1997 mendapatkan rating penonton sebesar $4,2 \%$ atau sekitar lebih dari 150 juta pemirsa di Tiongkok. Musik pop Korea terutama musik tarinya mulai dikenal para remaja Tionghoa setelah diperkenalkan pada awal tahun 1997 oleh program radio bernama Seoul Music Room, di Beijing. Saat menentukan yang membuat budaya pop Korea berkobar di Tiongkok adalah konser boyband bernama H.O.T yang diselenggarakan di Beijing Workers' Gymnasium, Februari 2000. Laporan berita Korea memakai istilah Hallyu atau Gelombang Korea untuk menggambarkan konser ini. Gelombang Korea dikenal di dalam sebuah artikel terbitan Beijing Youth Daily pada awal November 1999 yang kemudian dikenal oleh masyarakat Korea hingga kini (Kedubes Korea, 2015).

Menurut Yulius (2015), di dalam kata pengantar untuk buku The Korean Wave, Youna Kim mengungkapkan bahwa sejak tahun 1990-an, Korea Selatan telah berkembang menjadi salah satu pusat produksi budaya populer yang diekspor ke berbagai belahan dunia, seperti Jepang, China, Taiwan, Hongkong, bahkan juga negeri kita sendiri. Inilah yang disebut dengan fenomena Hallyu atau Korean Wave. Kata "hallyu" sendiri terderi dari dua kata, yaitu "han" yang merujuk pada orang Korea, dan "ryu" yang mengacu kepada ombak atau gelombang. Seperti arti dari namanya, fenomena ini memang seperti ombak dengan arusnya yang mengalir dari Korea Selatan menuju berbagai tempat, membawa pengaruh dan tren yang signifikan di dalam dunia hiburan. 
Menurut Andaara (2018), kata hijrah sudah sangat umum didengar oleh sebagian dari kita. Sebuah kata yang dapat mengubah hidup. Sebuah kata yang dapat menghapus kegelapan dengan cahaya keimanan. Belakangan ini, hijrah sangat familier di telinga masyarakat, dari anak muda hingga dewasa. Tren mendadak tersebut memberikan dampak positif bagi banyak kalangan. Ada dari mereka yang memberikan aksi nyatanya dengan berhijrah. Selain itu, ada juga yang memanfaatkannya untuk berbisnis pakaian-pakaian hijrah dan tidak dipungkiri ada juga dari mereka yang kontra dengan istilah hijrah.

Hijrah adalah perpindahan. Sebagaimana yang pernah dicontohkan oleh Rasulullah Saw bersama para sahabatnya yang mulia ketika mereka berpindah dari kota Makkah ke kota Madinah. Akan tetapi, hijrah bukanlah sembarang berpindah tempat. Hijrah bukanlah perpindahan yang tanpa maksud dan tanpa tujuan. Hijrah bukan pula perpindahan yang bertujuan akhir mencari tempat baru yang nyaman untuk berleha-leha. Hijrah adalah sebuah langkah atau juga dapat disebut sebagai langkah pembuka untuk menempuh perjuangan yang lebih besar dan meraih kesuksesan. Pasca hijrah kota Madinah, Rasulullah Saw bersama para sahabat memulai babak baru perjuangan meninggikan panji-panji Islam. Dalam waktu yang relatif singkat, dari kota Madinah ini, Islam kemudian semakin besar dan semakin luas pengaruhnya hingga ke berbagai penjuru dunia. Sejatinya, semangat hijrah adalah semangat perpindahan dari situasi yang tidak baik kepada situasi yang baik. Perpindahan dari suatu kondisi yang sudah baik kepada kondisi yang lebih baik lagi. Semangat itu akan terus relevan hingga saat ini dan nanti (Gymnastiar, 2012).

Hijrah berasal dari bahasa Arab, yang berarti meninggalkan. Dalam konteks sejarah Islam, hijrah adalah kegiatan migrasi yang dilakukan oleh Nabi Muhammad Saw bersama para sahabat dari kota Makkah ke kota Madinah dengan tujuan untuk mempertahankan dan menegakkan risalah Allah Swt (Andaara, 2018).

Media Sosial Instagram media komunikasi yang efektif dalam bersosialisasi dengan masyarakat, sebagai bentuk kreatifitas para ahli teknologi yang hadir ditengah masyarakat. Dewasa ini media sosial sangat digemari oleh banyak orang terutama generasi milenial didalamnya terdapat media sosial dan mempunyai karakter berbeda. Karakter Informasi, Karakter Arsip. Karakter Interaksi, Dari beberapa macam karakter media sosial salah satu karakter interaksi tepat dijadikan sebagai interaksi untuk berdakwah di media sosial. Media Sosial Instagram Sebagai Media Dakwah dapat digunakan oleh siapapun, sebagai sarana untuk berbagi foto dan video sebagai media untuk berdakwah (Ismail, dkk, 2018).

Menurut Ismail, dkk (2018), instagram merupakan singkatan dari "instant-telegram" yang berarti "mengirimkan berita secara langsung". Disusun dari dua kata, "Insta" dan "Gram". Arti dari kata pertama diambil dari 
istilah "Instan" atau serba cepat/mudah. Sedangkan kata "Gram" diambil dari "Telegram" yang maknanya dikaitkan sebagai media pengirim informasi yang sangat cepat. Sebuah aplikasi berbagi foto yang memungkinkan pengguna mengambil foto, menerapkan filter digital, dan membagikannya ke berbagai layanan jejaring sosial. Satu fitur yang unik di Instagram adalah memotong foto menjadi bentuk persegi, sehingga terlihat seperti hasil DSLR.

Komponen dalam Instagram logo gambar kamera yang didesain semenarik mungkin, hanya fokus untuk memposting foto dan video. Dalam Instagram terdapat beberapa komponen, yaitu halaman, pencarian, share, dan efek foto. Intreraksi media sosial follow (pengikut), tanda like, dan love, comment (komentar), caption (deskripsi) foto dapat ditambahkan juga lokasi foto serta menandai oarng yang ada dalam foto tersebut (Ismail, dkk, 2018).

\section{Hasil Dan Pembahasan}

Profil Halaman awal pada akun media sosial instagram @xkwavers memberikan info tentang akun@xkwaversyang memanafaatkan halaman awal akun dengan identitas akun @xkwavers dengan profil, tagline, kontak, informasi akun fanspage, alamat pemilik akun, unggahan, jumlah pengikut dan jumlah yang diikuti.

Sejarah akun@xkwavers adalah salah satu nama akun di media sosial instagram yang dibuat dan didaftarkan oleh Ustadz Fuadh Naim. Latar belakang akun ini muncul berangkat dari latar belakang pemilik kaun itu sendiri yang "pernah tenggelam" dalam dunia hiburan korea dan terjebak di dalamnya pada suatu fanatisme yang tidak berujung. Menurut Fauziah (2019), Ustadz Fuadh Naim merupakan seorang mantan Fanboy (istilah untuk orang yang fanatik terhadap tren Korea) dari tahun 2007. Adapun menurut Naim (2019), berdasarkan tulisan di halaman resmi dari buku hasil adaptasi akun@xkwavers, yang juga ditulis oleh Ustadz Fuadh Naim, termuat alasan dibuatnya akun instagram (a)xkwavers sekaligus alasan ditulisnya buku dengan judul "Pernah Tenggelam", yaitu:

"Ini Buku Tentang Hallyu. Yang satu begitu mencintai nya sampai gila. Yang satu begitu membencinya hingga mencela. Buku ini dipersembahkan bagi yang suka maupun benci dengan Hallyu (Korean Wave). Agar yang suka tahu dimana batasnya. Agar yang benci tahu bagaimana adabnya."

Berdasarkan sejarah dibuatnya akun isntagram@xkwaves, dapat diketahui visi dan misi dari Ustadz Fuadh Naim yang tidak lain merupakan pemilik akun@xkwaves, yaitu menyampaikan pesan dakwah dengan prinsip merangkul tanpa memukul, memberi solusi tanpa mencaci, dan mengatasi "Halu" pada "Hallyu" sebgaimana tercantum di dalam biodata akun tersebut. Sealin itu, yang coba untuk ditekankan oleh Ustadz Fuadh Naim adalah bahwa berdakwah itu ada baiknya menyesuaikan dengan mitra dakwahnya (mad'u) , dimana tanpa perlu mencaci, menghina, ataupun menghakimi, seorang pendakwah seharusnya bisa berdakwah 
dengan sebaik mungkin tanpa menyakiti hati mitra dakwahnya (mad'u).

$$
\text { Intisari dari akun@xkwaves }
$$
sebenarnya sudah dapat dilihat dari tiga unggahan awal pada akun tersebut, ketiganya diunggah di hari yang sama yaitu pada tanggal 31 Agustus 2018. Unggahan pertama sekaligus perdana dengan deskripsi unggahan (caption):

"Cinta itu membuatku setia menatapmu, meski mata ini perih dan berdarah. Cinta itu membuatku setia mengejarmu, meski nafas ini sesak, nyaris meledak. Cinta itu membuatku hanya melihat baik pada semua kesalahanmu. Cinta itu mengindahkan rupamu. Cinta itu memuliakan lakumu. Tapi sayang... Cinta yang sama, sedang menenggelamkanku. \#Pernah Tenggelam \#한류히즈라 \#YukNgaji."

Berdasarkan deskripsi unggahan perdana di akun@xkwavers, didapatkan suatu pesan dakwah yang tersirat tentang perasaan cinta yang berlebihan kepada makhluk tidak akan pernah baik hasilnya. Dalam konteks ini cinta kepada budaya asing (baca: Korea), yang pada akhirnya hanya akan menenggelamkan yang mencintai pada hal-hal yang negatif. Sebagaimana diketahui bahwa cinta pada dasarnya adalah fitrah setiap manusia yang dianugerahkan oleh Allah Swt. Di dalam sebuah hadits dijelaskan tentang cinta:

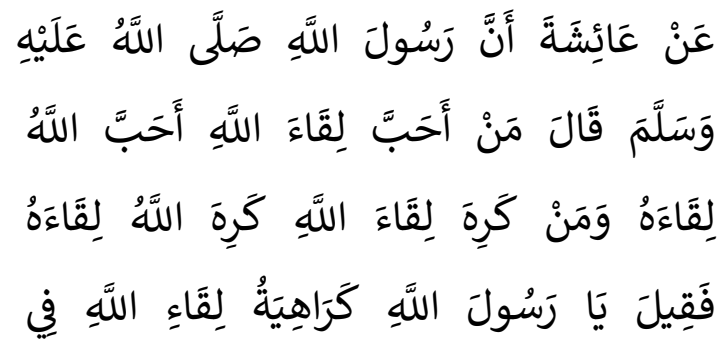

كَرَاهِيَةِ لِقَاءِ الْمَوْتِ فَكُلُّنَا يَكْرَهُ الْمَوْتَ قَالَ لَا إِنَّمَا ذَاكَ عِنْدَ مَوْتِهِ إِذَا بُسِّرَ بِبرحْمَةِ اللَّهِ وَمَغْفِفرَتِهِ أَحَبَّبَ لِقَاءَ اللَّهِ فَأَحَبَّب اللَّهُ لِقَاءَهُ وَاذِاَا بُشِّرَ بِعَذَابِ اللَّهِ كَرِة لِقَاءَ اللَّهِ وَكَرَة اللَّهُ لِقََاءَهُ

"Dari 'Aisyah ra. bahwa Rasulullah shallallahu 'alaihi wasallam bersabda: "Barangsiapa cinta bertemu Allah, maka Allah pun cinta bertemu dengannya, dan barangsiapa benci bertemu dengan Allah, maka Allah pun benci bertemu dengannya." Maka di tanyakan; "Wahai Rasulullah, kalau begitu kebencian terhadap perjumpaan dengan Allah, berarti benci terhadap kematian? Padahal kami benci terhadap kematian." Beliau bersabda: "Bukan, akan tetapi hal itu saat kematiannya tiba. Jika ia dikabarkan akan mendapatkan rahmat Allah dan ampunan-Nya, lalu ia cinta berjumpa dengan Allah, maka Allah pun cinta berjumpa dengannya, dan jika di kabarkan ia akan mendapatkan adzab Allah, lalu ia benci berjumpa dengan Allah, maka Allah pun benci berjumpa dengannya."” (HR. Ibnu Majah, Nomor Hadits: 4254).

Unggahan kedua dengan deskripsi unggahan (caption):

"Niat adalah janji yang butuh bukti, bahwa ia akan ditepati. Jalan pasti diberi, asal kita mau mencari. Namun tak akan sampai jika langkah kita seringkali berhenti. Akun ini hanyalah jalan. Gerakan ini hanyalah harapan. Diri kita sendiri lah yang akan membuktikan. Akankah hijrah ini sebatas ucapan, Atau kesungguhan niat dari hati terdalam. Mari saling mencintai dalam ketaatan Mari saling merangkul ditengah perbedaan Eh nggak beda, kita sama kok. Sama sama \#PernahTenggelam. \#한류히즈라 \#YukNgaji." 
Berdasarkan deskripsi unggahan kedua di akun@xkwavers, didapatkan beberapa pesan dakwah yang tersirat, yaitu:

a. Segala sesuatu tergantung pada niatnya, sebagaimana salah satu hadits populer disebutkan bahwa:

الْقَمَةَ بْنَ وَقَّاصِ اللَّيْيََّّ يَقُولُ سَمِعْتُ عُمَرَ بْنَ الْخَطَّابِ رَضِيَ اللَّهُ عَنْهُ عَلَى الْمِنْبَرِ قَالَ سَمِعْتُ رَسُولَ اللَّهِ صَلَّى

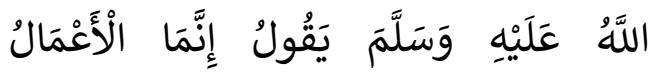

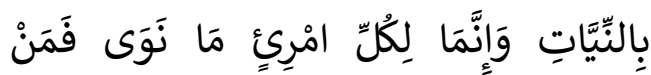
كَانَتْ هِجْجَرَتُهُ إِلَى دُنْيَا يُصِيُبهَا أَوْ إِلَى

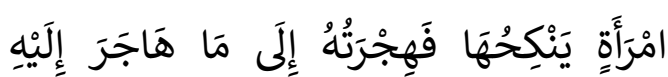

"Alqamah bin Waqash Al Laitsi ra. berkata; saya pernah mendengar Umar bin Al Khaththab ra. diatas mimbar berkata; saya mendengar Rasulullah shallallahu 'alaihi wasallam bersabda: "Semua perbuatan tergantung niatnya, dan (balasan) bagi tiap-tiap orang (tergantung) apa yang diniatkan; Barangsiapa niat hijrahnya karena dunia yang ingin digapainya atau karena seorang perempuan yang ingin dinikahinya, maka hijrahnya adalah kepada apa dia diniatkan"' (HR. Bukhari, Nomor Hadits: 1).

b. Hidayah itu dicari, bukan dinanti. Allah Swt tidak akan serta merta mengubah nasib seseorang hingga orang itu berusaha untuk merubah nasibnya sendiri. Sebagaimana yang terdapat di dalam QS.Ar-Ra'd [13] ayat 11:

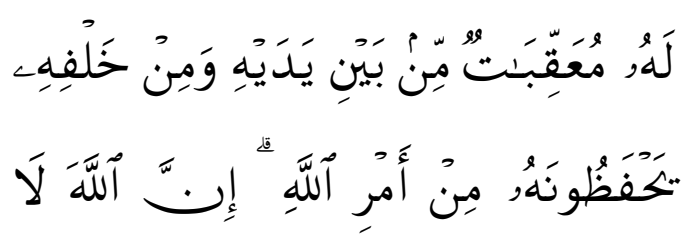

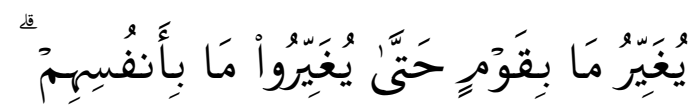

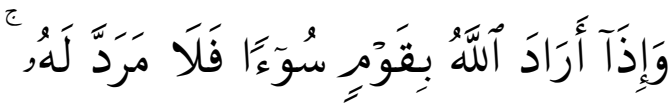

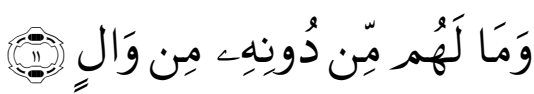

"Bagi manusia ada malaikat-malaikat yang selalu mengikutinya bergiliran, di muka dan di belakangnya, mereka menjaganya atas perintah Allah. Sesungguhnya Allah tidak merubah keadaan sesuatu kaum sehingga mereka merubah keadaan yang ada pada diri mereka sendiri. Dan apabila Allah menghendaki keburukan terhadap sesuatu kaum, maka tak ada yang dapat menolaknya; dan sekali-kali tak ada pelindung bagi mereka selain Dia."

c. Saling mencintai di antara sesama Muslim, dalam bingkai Ukhuwah Islamiyyah. Seperti dalam sebuah hadits yang menyebutkan bahwa:

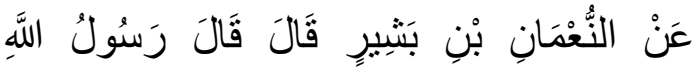

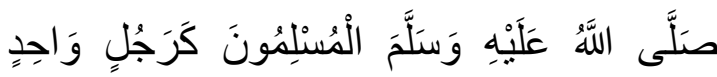

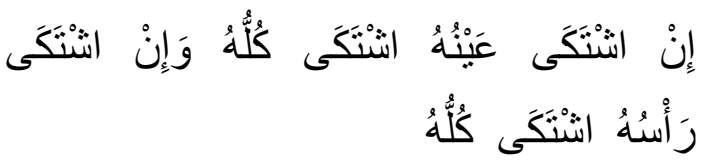

"dari An Nu'man bin Bisyir ra. dia berkata; Rasulullah shallallahu 'alaihi wasallam bersabda: bersabda: "Orang-orang muslim itu, bagaikan seorang laki-laki, apabila matanya sakit, maka sakitlah seluruh tubuhnya. Dan apabila kepalanya yang sakit, maka sakit pulalah seluruhnya."” (HR. Muslim, Nomor Hadits: 4687).

Unggahan ketiga dengan deskripsi unggahan (caption):

"Pesonanya kukagumi. Tingkahnya kuikuti. Musiknya sebagai pelipur hati. Hanya mereka yang mengerti. Aku cinta mati! Bisik hati tak peduli. Tenggelam lebih jauh lagi. Manakala waktu terus berganti. Hingga suatu 
hari, aku menyadari, bukan cinta yang membutakan diri. Tapi kita yang menutup mata juga hati. Mari, kembalikan cinta kepada Yang Maha Mencintai. \#PernahTenggelam \#한류히즈라 \#YukNgaji."

Berdasarkan deskripsi unggahan ketiga di akun@xkwavers, didapatkan suatu pesan dakwah yang tersirat tentang hati dan pentingnya menjaga hati. Di dalam sebuah hadits dijelaskan bahwa:

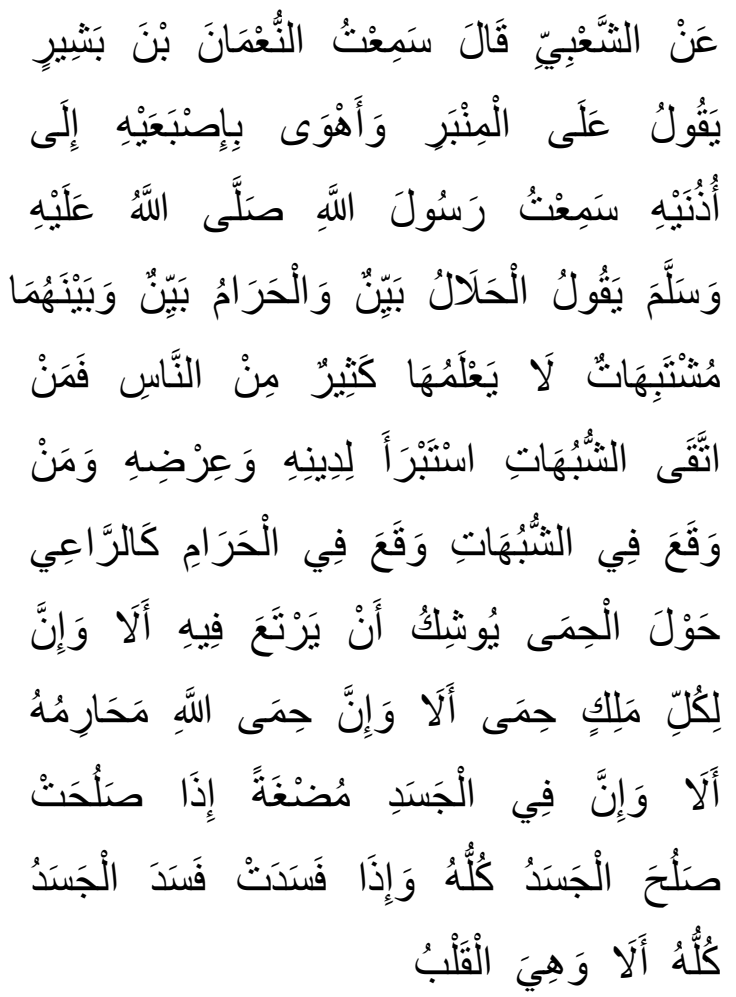

"Dari Asy Sya'bi ra. dia berkata; saya mendengar An Nu'man bin Basyir ra. berkata di atas mimbar dan mengisyaratkan dengan jari-jarinya di kedua telinganya, "Saya mendengar Rasulullah shallallahu 'alaihi wasallam bersabda: "(Sesuatu) yang halal telah jelas dan yangharam juga telah jelas, dan di antara keduanya ada perkara Syubhat (samar-samar) yang kebanyakan orang tidak mengetahuinya. Barangsiapa dapat menjaga diri dari perkara syubhat itu berarti ia telah menjaga agama dan kehormatannya, dan barangsiapa terjatuh ke dalam perkara syubhat berarti ia telah terjatuh dalam keharaman. Seperti penggembala yang menggembala hewan ternaknya di sekitar daerah terlarang, dikhawatirkan hewannya akan masuk ke wilayah yang terlarang itu. Ketahuilah, bahwa setiap raja memiliki larangan, dan larangan Allah adalah sesuatu yang di haramkannya. Ketahuilah, di dalam tubuh terdapat segumpal darah, jika ia baik maka akan baiklah seluruh tubuh. Namun jika ia rusak maka akan rusak pulalah seluruh tubuh, ketahuilah bahwa segumpal darah tersebut adalah hati."

\section{Kesimpulan}

Berdasarkan pembahasan di atas, diketahui makna pesan dakwah pada tiga postingan pertama akun instagram@xkwaves adalah:

a. Cinta yang berlebihan kepada makhluk tidak akan pernah baik hasilnya. Dalam konteks ini cinta kepada budaya asing (baca: Korea), yang pada akhirnya hanya akan menenggelamkan yang mencintai pada hal-hal yang negatif. Sebagaimana diketahui bahwa cinta pada dasarnya adalah fitrah setiap manusia yang dianugerahkan oleh Allah Swt.

b. Segala sesuatu tergantung pada niatnya. "Barangsiapa niat hijrahnya karena dunia yang ingin digapainya atau karena seorang perempuan yang ingin dinikahinya, maka hijrahnya adalah kepada apa dia diniatkan."

c. Hidayah itu dicari, bukan dinanti. Allah Swt tidak akan serta merta mengubah nasib seseorang hingga orang itu berusaha untuk merubah nasibnya sendiri (QS. $A r-R a ' d$ [13]: 11).

d. Saling mencintai di antara sesama Muslim, dalam bingkai Ukhuwah Islamiyyah.

e. Pentingnya menjaga hati. "Ketahuilah, di 
dalam tubuh terdapat segumpal darah, jika ia baik maka akan baiklah seluruh tubuh. Namun jika ia rusak maka akan rusak pulalah seluruh tubuh, ketahuilah bahwa segumpal darah tersebut adalah hati.”

\section{Daftar Pustaka}

Andaara, M. R. 2018. Stop Talking And Start Hijrah. Jakarta: PT. Elex Media Komputindo.

Aziz, M. A. 2017. Ilmu Dakwah, Edisi Revisi. Jakarta: Penerbit Kencana.

Fauziah. 2019. Review Buku \#PernahTenggelam: Siapa Bilang Korea itu Haram?.(https://www.kompasiana.co $\mathrm{m} /$ fauziah $98 / 5 \mathrm{c} 761 \mathrm{c} 546 \mathrm{ddcae} 553 \mathrm{~b} 20 \mathrm{~d}$ 472/siapa-bilang-korea-itu-haram-revi ew-buku-pernahtenggelam?page=all). (Diakses: 31 Oktober 2019. Pukul 13.30 WIB).

Gymnastiar, A. 2012. Hijrah Gerbang Kesuksesan. Bandung: SMS Tauhiid.

Illaihi, W., dan Harjani H. P. 2018. Pengantar Sejarah Dakwah. Jakarta: Penerbit Kencana.

Ismail, A. I. 2018. The True Da'wa: Menggagas Paradigma Baru Dakwah Era Milenial. Jakarta: Penerbit Kencana.

Ismail, N., Zainal A., dan Uwes F. 2018. Pesan Dakwah Tentang Nikah Di Medi Sosial Instagram. Tabligh: Jurnal Komunikasi Dan Penyiaran Islam. Vol. 3 (1): 22-45. ISSN: 2622-9773.

Kedutaan Besar Republik Korea. 2015. Hallyu : Gelombang Korea (한류:Korea Wave).

(http://overseas.mofa.go.kr/id-id/wpge /m 2741/contents.do) (Diakses: 31 Oktober 2019. Pukul 13.15 WIB).
Naim, F. 2019. Ini Buku Tentang Hallyu. (https://pernahtenggelam.com/). (Diakses: 31 Oktober 2019. Pukul 14.00 WIB).

Tasmara, T. 1997. Komunikasi Dakwah. Cetakan Ke-2. Jakarta: Gaya Media Pratama.

Yulius, H. 2015. 100+ I Heart Seoul. Jakarta: Grasindo. 